\title{
Social Marketing Studies on Health Interventions in Turkey: A Systematic Review and Validation on Theory and Model Use
}

\section{Tolga ŞENTÜRK iD a}

a İzmir Katip Çelebi University, İzmir, Türkiye. tolga.senturk@ikc.edu.tr

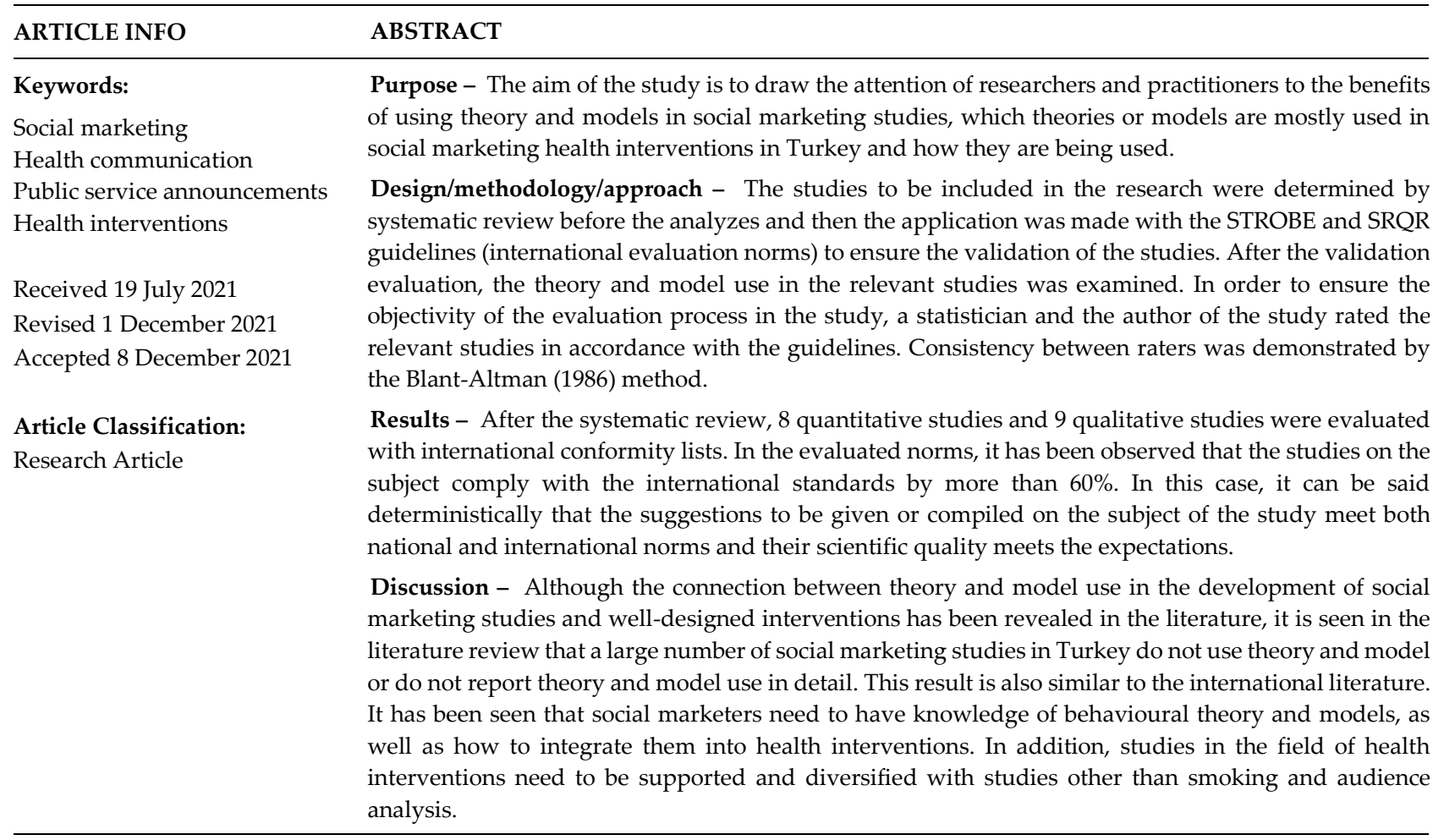

\section{INTRODUCTION}

Today, humanity is facing a multitude of challenges ranging from but not limited to epidemics, income and racial inequality, barriers to accessing education and health services, environmental degradation and climate change (UN, 2020). It is essential to address these thematic challenges to ensure a sustainable world (Cassar et al., 2013; Ekren and Senturk, 2021). Producing the desired results in addressing these challenges depend upon creating social awareness and realization of such desired behaviors. Governments, businesses and civil society needs to be collectively mobilized to ensure the desired changes takes place (Rundle-Thiele et al., 2019:161).

In the last sixty years, some actors in marketing ( see Bickman, 1972; Cheng et al., 2010; Geller et al., 1981; Geller et al., 1983; Kotler and Zaltman, 1971; McKenzie-Mohr 2000; Wiebe, 1952) did not remain indifferent towards the social problems of their times, turning their experiences and insights into starting a new marketing approach. The literature has expended since Wiebe (1952) first described the marketing efforts for the desired social transformation as "Social Marketing".

Expectations for solutions to existing challenges in the world lead governments, businesses, civil society and all interested parties to deal with social problems and to persuade target audiences to adopt desired changes. However, the effectiveness of campaigns to address such challenges remains an important issue of debate (Akbar et al., 2021). Most of the studies show that providing information to the society in campaigns do not have the desired behavioral change in individuals and remain at the basic level of raising awareness (Buyucek et al., 2016; McKenzie-Mohr and Smith, 1999). 
The effects of public service advertisements and campaign videos did not yet reach the level of effect of commercial advertisements. For example, getting individuals to adhere to the measures of the Covid-19 pandemic is much more difficult and complex than persuading people to buy a product through advertisements. There are obstacles to the implementation of COVID-19 measures, such as people's willingness to participate in social activities such as entertainment and sports, cultural norms and etiquette that encourage their participation in funerals and weddings. The diversity and compulsion of these social barriers hinders the formation of a sustainable behavior perception and a real change in behavior (Çelik, 2016). Therefore, new perspectives and approaches are needed to provide social benefit.

The social marketing approach has long been used in public health interventions to achieve desired behavioral change in target audiences (see Futterman et al., 2001; Gallivan et al., 2007; Long, et al. 2008; Pang et al., 2017; 2018; Wymer, 2015). Through social marketing campaigns in that field, 1) increase in awareness of target audiences on health interventions, 2) dissemination of educational materials on diseases and treatment practices, and 3) provision of support for preventive health practices are achieved. And for better results, the use of theory and models has been emphasized in social marketing studies on health interventions since the 1990s (Hastings and Saren, 2003).

The importance of using theory and model in designing, implementing and evaluating effective social marketing campaigns is highlighted by many authors (see Hastings and Saren, 2003, Lafabvre, 2000; Luca and Suggs, 2013; Kotler and Lee, 2008; Rundle-Thiele, 2019). In terms of ensuring the effectiveness of health campaigns and understanding how to achieve the desired goals, it is extremely valuable to determine the frequency and scope of the use of theory and model in social marketing studies on health interventions in Turkey. Knowing the theories and models that can be used for the effectiveness of future research and campaign designs, and identifying which theories and models are used in which types of health interventions will be of great benefit to researchers and practitioners. In this context, the aim of the present study is to draw the attention of researchers and practitioners to the benefits of using theory and models in social marketing studies, which theories or models are mostly used in social marketing studies in the field of public health in Turkey, how they are being used and the application of theory and model which is discussed in the evaluation part of the study.

In the validation and systematic review carried out within the scope of the research, only the studies with the title of social marketing were not discussed. Due to the relevance of many social marketing campaigns and researches on health interventions with social advertising, health communication and public service advertisement, that studies were also included in the research.

\section{METHOD}

\section{The Model and the Population of the Research}

The motivation of the study is to contribute to the use of behavioral theories and models as an applicable guide in social marketing studies on health interventions. It is seen that social advertisements, health communication activities and public service announcements are frequently used in social marketing studies on health (see Becerikli, 2012; Çınarlı, 2008; Gençoğlu, 2017; Okay, 2007). For this reason, studies on health communication, public service announcements and social advertisements on health interventions in Turkey were also included in the model of the study.

\section{Data Collection and Research Sample}

The studies to be included in the research were determined by systematic review before the analyzes and then the application was made with the STROBE and SRQR guidelines (international evaluation norms) to ensure the validation of the studies. After the validation evaluation, the theory and model use in the relevant studies was examined.

Electronic Information Resources Databases Open to TÜBİTAK access were used in the research and only research articles were included in the study. With "social marketing" term, 91 articles were identified between 1983 and 2020 in the relevant databases. Again in the same databases, 57 articles were detected between 2002 and 2020 in the search made with the term "public service advertisement". Finally, in the search made with the term "health communication" 115 studies were identified between 2002 and 2020 . Thus, a total of 263 articles were reached in the research. First of all, studies on subjects unrelated to health interventions were excluded. 
Then, among the studies on health interventions, studies that use theory and models or that refer to them were determined and subjected to literature review. The review process in question is shown in Fig. 1.

In order to ensure the objectivity of the evaluation process in the study, a statistician and the author of the study evaluated the relevant studies in accordance with the guidelines. Consistency between researchers was demonstrated by the Blant-Altman (Blant and Altman, 1986) method. In the Blant-Altman method, if the differences have a normal distribution, it is expected that the differences will be randomly distributed around zero and $95 \%$ of them will be between " $\mathrm{d} \pm 1.96 \mathrm{~s}$ ". Under this situation, it can be said that there is no relationship between the means and the differences. In this method, $\mathrm{d} \pm 1.96 \mathrm{~s}$ is called the "consistency of fit". It would be more accurate to find the table value (n-1) using the $t$ table for the degrees of freedom while finding the limits of fit for small samples. The limits of agreement in Fig. 2 and 3 were determined as the non-biased outliers between the researchers.

\section{Analyzes}

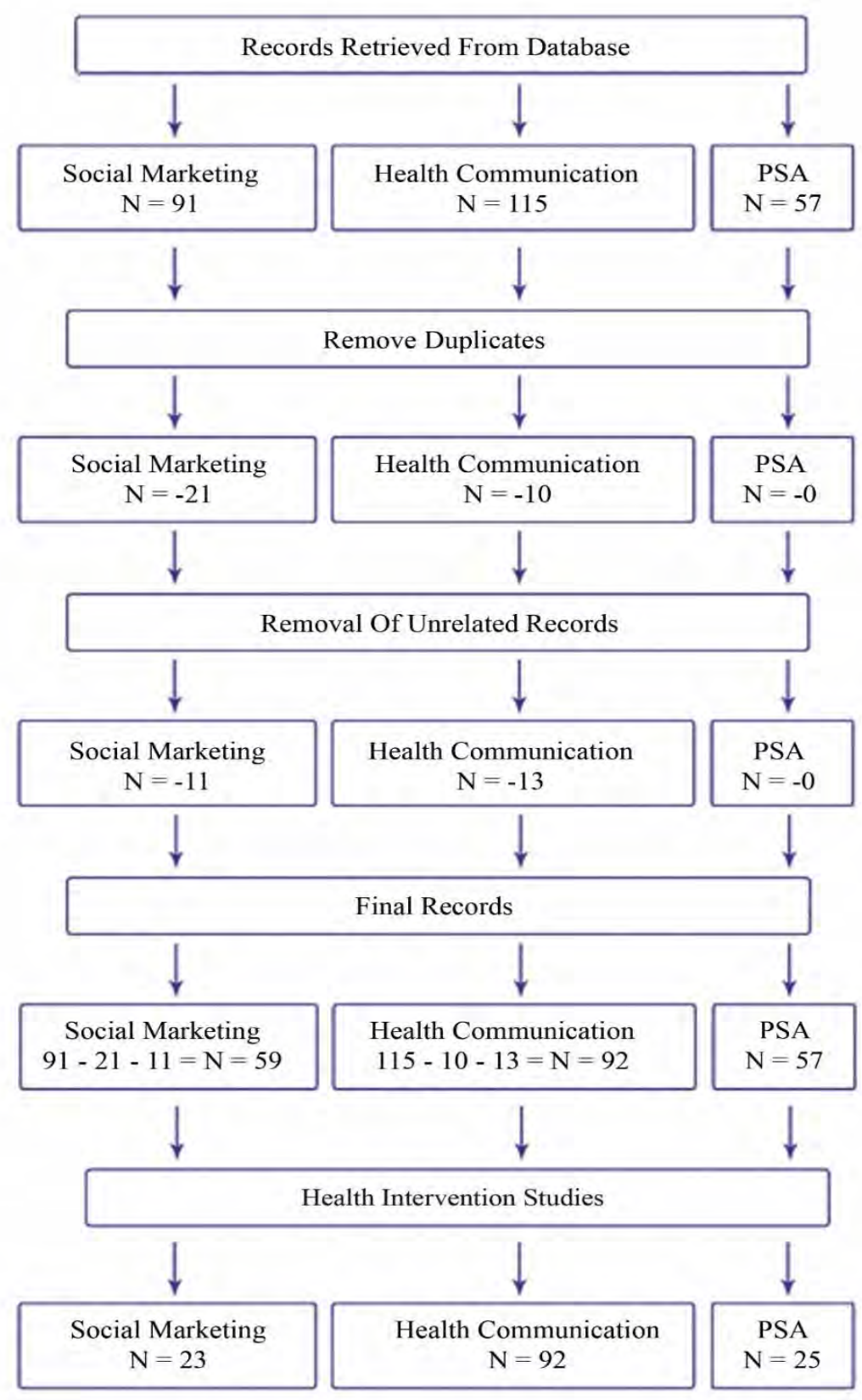

Figure 1. Systematic literature review process 
The systematic review part of the research started with a total of 263 studies. Among these studies, duplicate records and unrelated researches were removed. In this framework, the number of studies first decreased to 208. Later, studies in the field of health interventions were determined among the related studies. Thus, the number of studies researched decreased to 140. Among these studies, those that use theory and models or studies that refer to theories and models were determined. These studies are presented in the tables below.

\section{FINDINGS}

\section{Validation of the Studies Selected Through Systematic Review}

After the systematic review, 16 quantitative studies and 9 qualitative studies were evaluated with international conformity lists. Since one of these studies (SM2) used both qualitative and quantitative research methods, it was evaluated in terms of both methods. STROBE evaluation forms were used for quantitative studies and SRQR evaluation forms were used for qualitative studies. Studies were evaluated by an external independent statistician and the author as a double-blind rater, and the agreement between the raters was determined by Bland Altman charts. Evaluation of the studies included in the research was shown in Fig. 2, Fig.3, Table 1 and Table 2.

Figure 2. Bland-Altman Charts between Raters of Observational (Quantitative) Studies Evaluated Within the Framework of STROBE Criteria
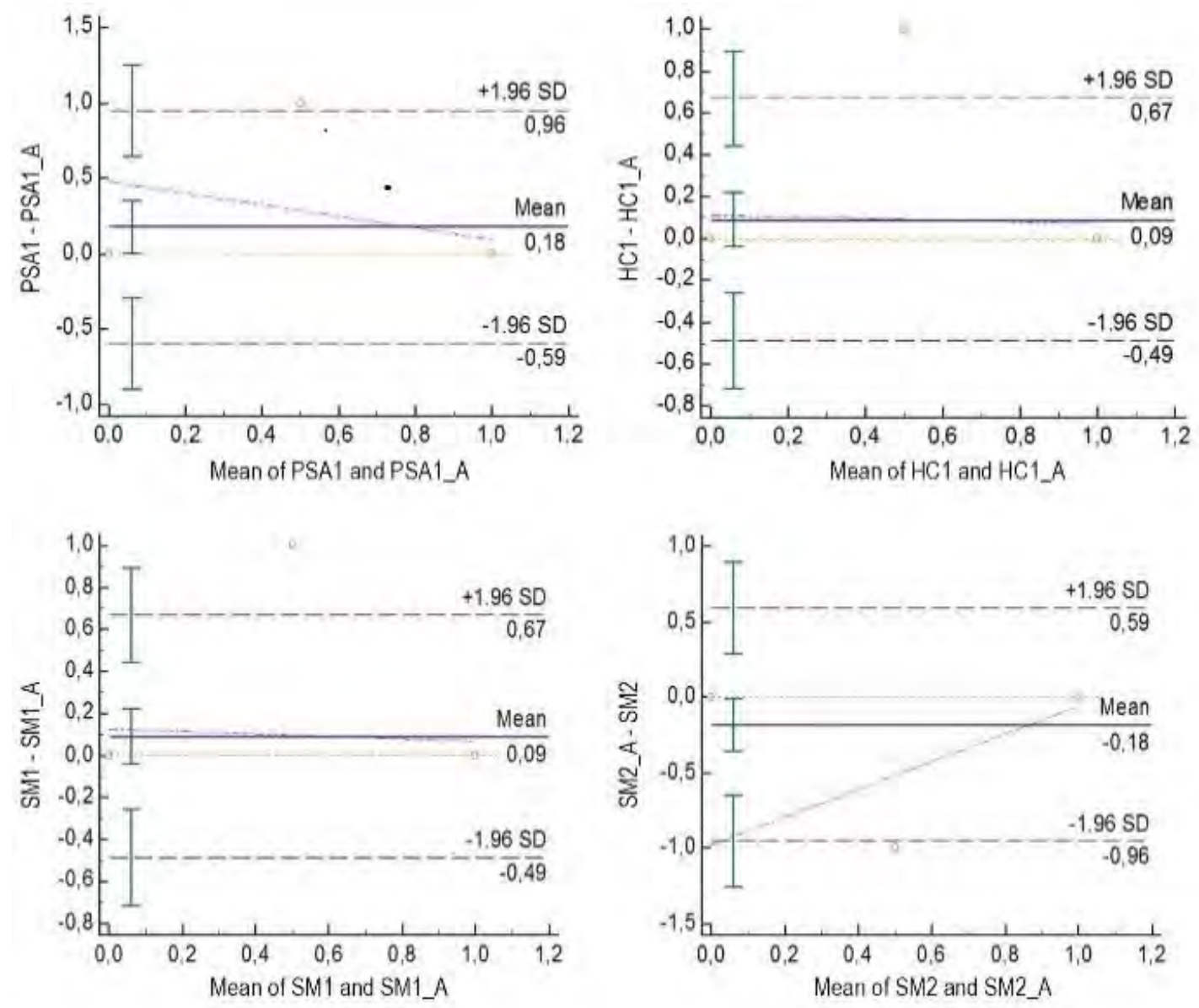
T. Şentürk 13/4 (2021) 3293-3309
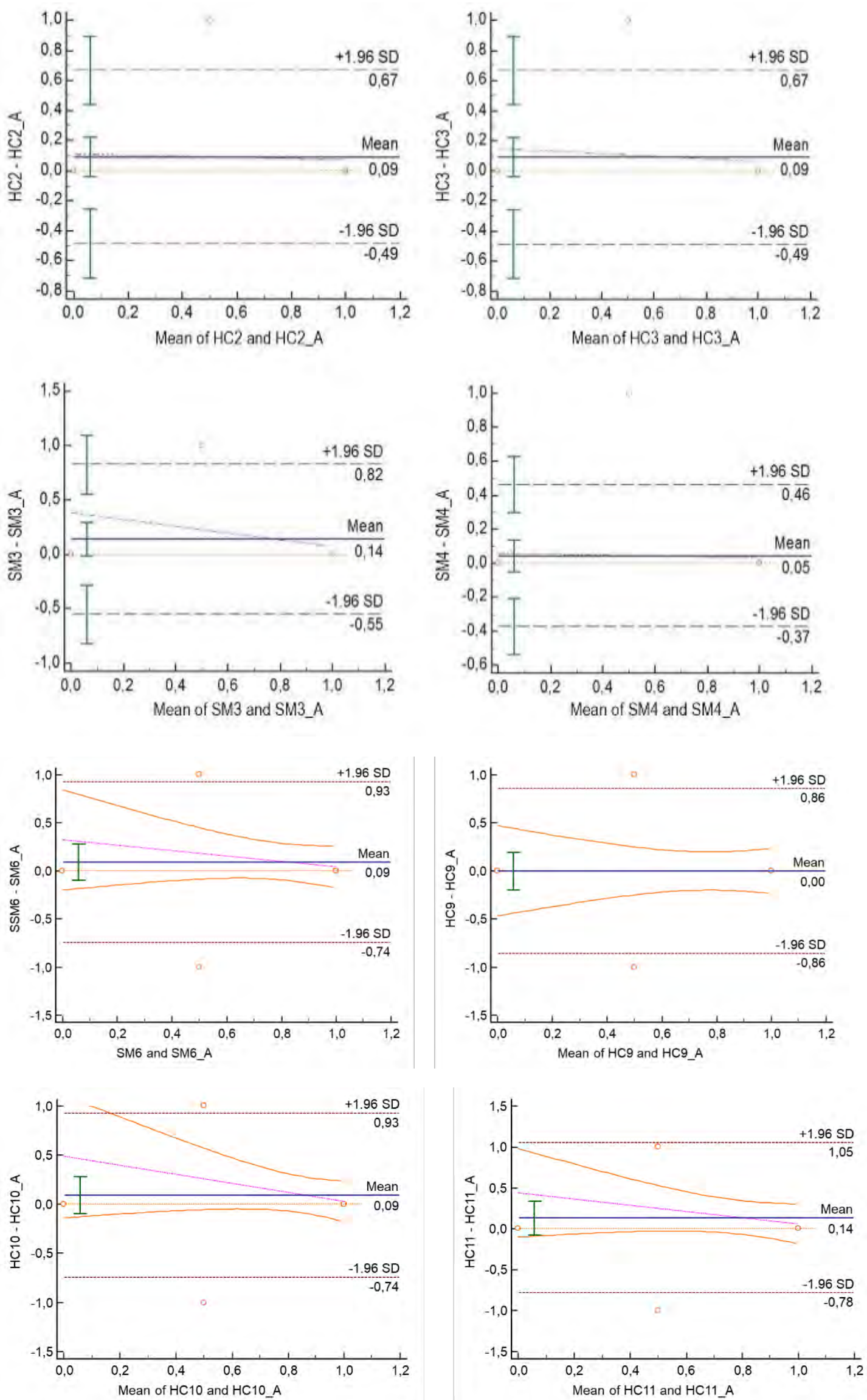

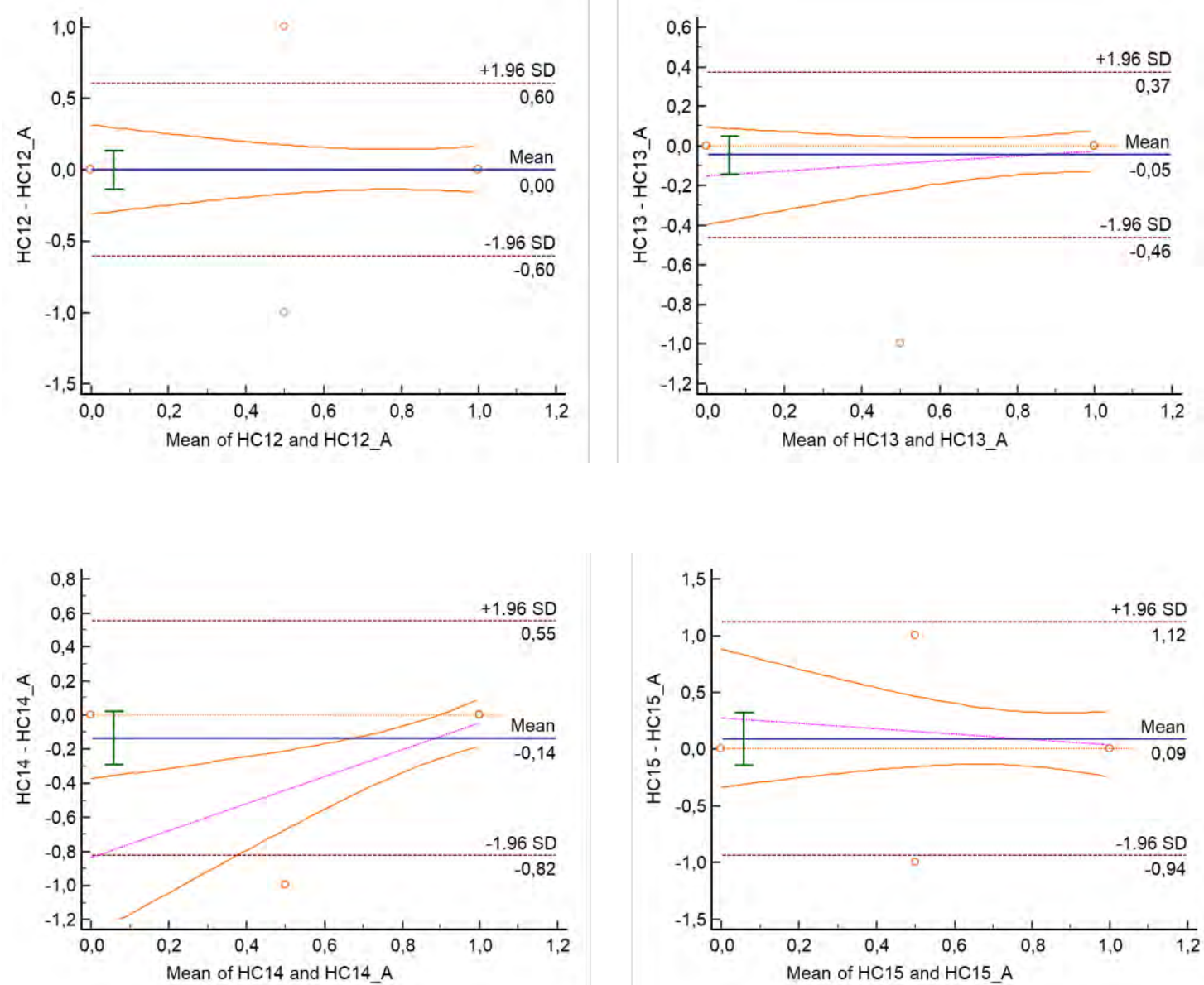

Table 1. STROBE Criteria Compliance Percentages and Bland Altman Difference-Confidence Intervals by Raters

\begin{tabular}{|l|l|l|l|l|l|l|l|}
\hline & \multicolumn{2}{|l|}{ Researcher 1 } & \multicolumn{2}{l|}{ Researcher 2 } & \multicolumn{3}{l|}{ Bland-Altman Results } \\
\hline STROBE Criteria $(\mathrm{n}=22)$ & $\mathrm{n}$ & $\%$ & $\mathrm{n}$ & $\%$ & $\mathrm{~d}$ & \multicolumn{2}{l|}{$\% 95$ confidence interval } \\
\hline SM1 & 15 & 68,2 & 13 & 59,1 & 0,18 & $-0,59$ & 0,96 \\
\hline SM2 & 21 & 95,5 & 17 & 77,3 & 0,009 & $-0,49$ & 0,67 \\
\hline SM3 & 19 & 86,4 & 16 & 72,7 & 0,009 & $-0,49$ & 0,67 \\
\hline SM4 & 14 & 63,6 & 13 & 59,1 & 0,009 & $-0,49$ & 0,67 \\
\hline HC1 & 14 & 63,6 & 12 & 54,5 & 0,009 & $-0,49$ & 0,67 \\
\hline HC2 & 14 & 63,6 & 12 & 54,5 & 0,18 & $-0,59$ & 0,96 \\
\hline HC3 & 16 & 72,7 & 14 & 63,6 & 0,14 & $-0,55$ & 0,82 \\
\hline PSA1 & 19 & 86,4 & 15 & 68,2 & 0,05 & $-0,37$ & 0,46 \\
\hline SM6 & 19 & 86,4 & 17 & 77,3 & 0,09 & $-0,098$ & 0,28 \\
\hline HC9 & 17 & 77,3 & 17 & 77,3 & 0,001 & $-0,19$ & 0,19 \\
\hline HC10 & 20 & 90,9 & 18 & 81,8 & 0,09 & 0,098 & 0,28 \\
\hline HC11 & 19 & 86,4 & 16 & 72,7 & 0,14 & $-0,07$ & 0,34 \\
\hline HC12 & 17 & 77,3 & 17 & 77,3 & 0,01 & $-0,14$ & 0,14 \\
\hline
\end{tabular}


T. Şentürk 13/4 (2021) 3293-3309

\begin{tabular}{|l|l|l|l|l|l|l|l|}
\hline HC13 & 18 & 87,8 & 19 & 86,4 & $-0,04$ & $-0,14$ & 0,05 \\
\hline HC14 & 18 & 81,8 & 21 & 95,5 & $-0,14$ & $-0,29$ & 0,020 \\
\hline HC15 & 18 & 81,8 & 16 & 72,7 & 0,09 & $-0,15$ & 0,32 \\
\hline
\end{tabular}

When Fig. 2 and Table 1 were examined, it was determined that the inter-rater agreement was high for quantitative studies. In the evaluated STROBE norms, it has been observed that the studies on the subject comply with the international standards by more than $60 \%$. In this case, it can be said deterministically that the suggestions to be given or compiled on the subject of the study meet both national and international norms and their scientific quality meets the expectations.

Figure 3. Bland-Altman Charts among Raters of Qualitative Studies Evaluated Within the Framework of SRQR Criteria
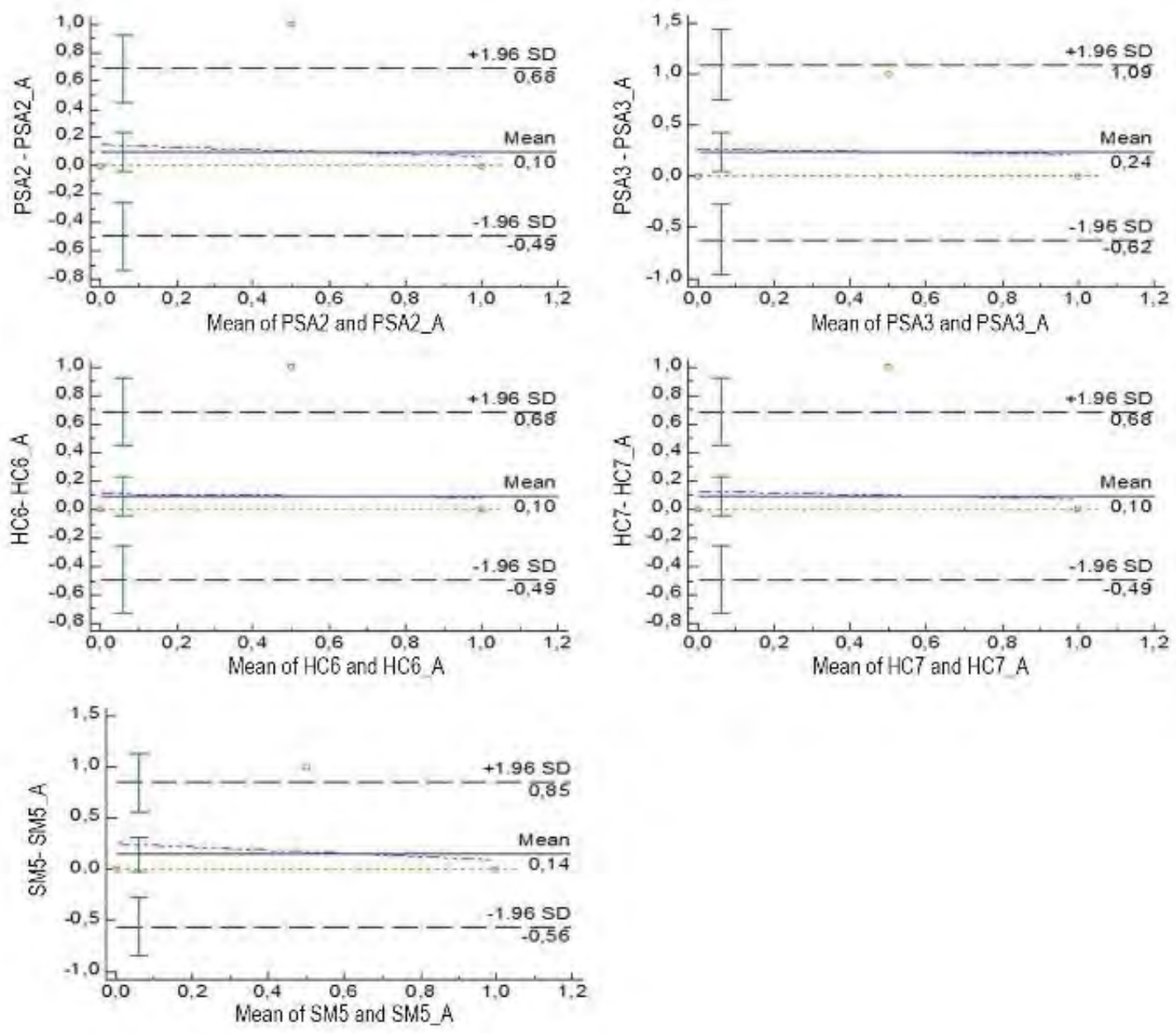

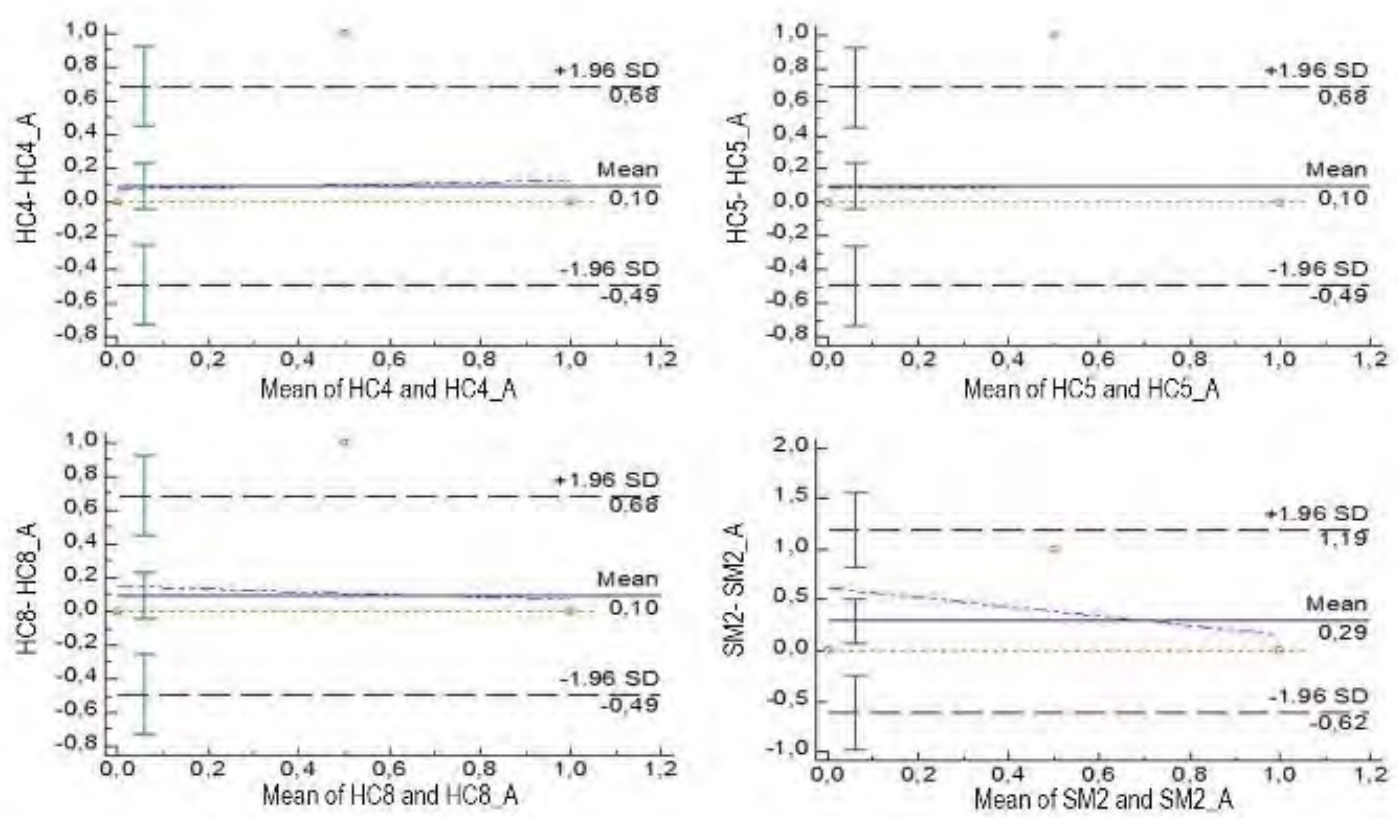

Table 2. SRQR Criteria Compliance Percentages and Bland Altman Difference-Confidence Intervals by Raters.

\begin{tabular}{|l|l|l|l|l|l|l|l|}
\hline & \multicolumn{2}{|l|}{ Researcher 1 } & \multicolumn{2}{l|}{ Researcher 2 } & \multicolumn{3}{l|}{ Bland Altman Results } \\
\hline SRQR Criteria $(\mathrm{n}=21)$ & $\mathrm{n}$ & $\%$ & $\mathrm{n}$ & $\%$ & $\mathrm{D}$ & \multicolumn{2}{l|}{$\% 95$ confidence interval } \\
\hline SM2 & 18 & 85,71 & 12 & 57,14 & 0,29 & $-0,62$ & 1,19 \\
\hline SM5 & 16 & 76,19 & 13 & 61,90 & 0,14 & $-0,56$ & 0,85 \\
\hline HC4 & 9 & 42,86 & 7 & 33,33 & 0,1 & $-0,49$ & 0,68 \\
\hline HC5 & 11 & 52,38 & 9 & 42,86 & 0,1 & $-0,49$ & 0,68 \\
\hline HC6 & 13 & 61,90 & 11 & 52,38 & 0,1 & $-0,49$ & 0,68 \\
\hline HC7 & 14 & 66,67 & 12 & 57,14 & 0,1 & $-0,49$ & 0,68 \\
\hline HC8 & 15 & 71,43 & 13 & 61,90 & 0,1 & $-0,49$ & 0,68 \\
\hline PSA2 & 15 & 71,43 & 13 & 61,90 & 0,1 & $-0,49$ & 0,68 \\
\hline PSA3 & 14 & 66,67 & 9 & 42,86 & 0,24 & $-0,62$ & 1,09 \\
\hline
\end{tabular}

When Fig. 3 and Table 2 were examined, it was determined that the inter-researcher agreement for qualitative studies was quite high. In the evaluated SRQR norms, it has been observed that the studies on the subject comply with the international standards by more than $60 \%$. In this case, it can be said deterministically that the suggestions to be given or compiled on the subject of the study meet both national and international norms and their scientific quality meets the expectations. 
Table 3. Use of Theory and Model in Social Marketing Studies

\begin{tabular}{|c|c|c|c|c|}
\hline Code & Researchers & Research Field & Research Type & $\begin{array}{l}\text { Theory and/or } \\
\text { Model Use }\end{array}$ \\
\hline SM1 & $\begin{array}{l}\text { Torun and } \\
\text { Ekinci, } 2014\end{array}$ & Smoking addiction & $\begin{array}{l}\text { Qualitative } \\
\text { research }\end{array}$ & $\begin{array}{l}\text { Exchange theory } \\
\text { was mentioned }\end{array}$ \\
\hline SM2 & $\begin{array}{l}\text { Çoknaz et al., } \\
2016\end{array}$ & Social marketing and physical activity & $\begin{array}{l}\text { Qualitative and } \\
\text { quantative } \\
\text { research }\end{array}$ & $\begin{array}{l}\text { Stage of change } \\
\text { model was used }\end{array}$ \\
\hline SM3 & $\begin{array}{l}\text { Nakıboğlu, } \\
2016\end{array}$ & Protecting form skin cancer & $\begin{array}{l}\text { Qualitative } \\
\text { research }\end{array}$ & $\begin{array}{l}\text { Planned action } \\
\text { theory was used }\end{array}$ \\
\hline SM4 & $\begin{array}{l}\text { Ekiyor and } \\
\text { Çetin, } 2017\end{array}$ & “E-Nabız" application & $\begin{array}{l}\text { Qualitative } \\
\text { research }\end{array}$ & $\begin{array}{l}\text { Exchange theory } \\
\text { was mentioned. }\end{array}$ \\
\hline SM5 & $\begin{array}{l}\text { Okmeydan, } \\
2018\end{array}$ & $\begin{array}{l}\text { Social marketing campaign steps on "Air } \\
\text { Without Cigarette Smoke Campaign" } \\
\text { (Dumansız Hava Sahası Kampanyası) }\end{array}$ & $\begin{array}{l}\text { Quantative } \\
\text { research }\end{array}$ & $\begin{array}{l}\text { Health promotion } \\
\text { model was used }\end{array}$ \\
\hline SM6 & Argan, 2016 & $\begin{array}{l}\text { Descriptive research for blood donation } \\
\text { campaign }\end{array}$ & $\begin{array}{l}\text { Qualitative } \\
\text { research }\end{array}$ & $\begin{array}{l}\text { Planned action } \\
\text { theory was used }\end{array}$ \\
\hline
\end{tabular}

In Table 3, data on the use of theory and model in social marketing studies in the field of health interventions are complied. When the related studies were examined, it was seen that the use of theory and model was mostly carried out in the descriptive research and campaign evaluation stages. In the SM1 coded study, it was investigated how effective the practices to struggle against smoking and how high taxes on tobacco products affected the reduction of smoking. By referring to the theory of change, the authors state that people try to multiply their benefits with the least cost. However, they did not associate exchange theory with the effect of reducing smoking and/or tax increases on cigarettes on consumer behavior. In the research coded SM2, the stages of change model (transtheoretical model) was used in the descriptive research phase, and primarily the needed target audience segmentation was carried out. Then, the necessary stages for the use of stages of change model in the health intervention phase were defined. In the study coded SM3, it was aimed to produce ideas about the health intervention by making descriptive research. Furthermore, the findings obtained in the research were tested and evaluated within the framework of the theory of planned behavior. In the SM4 coded study, the authors listed the marketing techniques and components to be considered in social marketing. In this context, the exchange theory is also mentioned. However, the exchange theory was not used at any stage, such as descriptive research, research design, or evaluation of findings. In the SM5 study, the authors used Kotler and Lee's (2008) campaign steps to test the design of a particular campaign. In the evaluation process, 
it was determined that the relevant campaign was designed in accordance with the health promotion model. In the SM6 coded study, theory of planned behavior was used for descriptive research. The author tried to determine the effect of perceived behavioral control, attitude and subjective norm, which were suggested by theory of planned behavior, on the blood donation intention and behavior.

Table 4. Use of Theory and Model in Health Communication Studies

\begin{tabular}{|c|c|c|c|c|}
\hline Code & Researchers & Research Field & $\begin{array}{l}\text { Research } \\
\text { Type }\end{array}$ & Theory and/or Model Use \\
\hline $\mathrm{HC} 1$ & $\begin{array}{l}\text { Bulduklu, } \\
2010\end{array}$ & $\begin{array}{l}\text { TV Health programs audience } \\
\text { motivation }\end{array}$ & $\begin{array}{l}\text { Qualitative } \\
\text { research }\end{array}$ & $\begin{array}{l}\text { Uses and gratifications theory } \\
\text { was used }\end{array}$ \\
\hline $\mathrm{HC} 2$ & $\begin{array}{l}\text { Koçak and } \\
\text { Bulduklu, } \\
2010\end{array}$ & $\begin{array}{l}\text { The motivation of the old } \\
\text { people to watch TV Health } \\
\text { programs }\end{array}$ & $\begin{array}{l}\text { Qualitative } \\
\text { research }\end{array}$ & $\begin{array}{l}\text { Uses and gratifications theory } \\
\text { was used }\end{array}$ \\
\hline $\mathrm{HC} 3$ & $\begin{array}{l}\text { Avcr and } \\
\text { Sönmez, } 2013\end{array}$ & $\begin{array}{l}\text { TV Health programs audience } \\
\text { motivation }\end{array}$ & $\begin{array}{l}\text { Qualitative } \\
\text { research }\end{array}$ & $\begin{array}{l}\text { Uses and gratifications theory } \\
\text { was used }\end{array}$ \\
\hline $\mathrm{HC} 4$ & Becerikli, 2012 & $\begin{array}{l}\text { Health communication and } \\
\text { PSAs }\end{array}$ & $\begin{array}{l}\text { Quantative } \\
\text { research }\end{array}$ & Reception theory was used \\
\hline HC5 & $\begin{array}{l}\text { Fidan and } \\
\text { Yetiş, } 2018\end{array}$ & $\begin{array}{l}\text { Health communication and } \\
\text { perception }\end{array}$ & $\begin{array}{l}\text { Quantative } \\
\text { research }\end{array}$ & Reception theory was used \\
\hline HC6 & $\begin{array}{l}\text { Özdemir, } \\
2019\end{array}$ & $\begin{array}{l}\text { Health communication and } \\
\text { behavioral intervention design }\end{array}$ & $\begin{array}{l}\text { Quantative } \\
\text { research }\end{array}$ & $\begin{array}{l}\text { Nudge theory and } \\
\text { psychological reactance } \\
\text { theory was used }\end{array}$ \\
\hline HC7 & $\begin{array}{l}\text { Şahin and } \\
\text { Duğan, } 2020\end{array}$ & $\begin{array}{l}\text { Health communication and } \\
\text { caps }\end{array}$ & $\begin{array}{l}\text { Quantative } \\
\text { research }\end{array}$ & $\begin{array}{l}\text { Elaboration likelihood model } \\
\text { was used }\end{array}$ \\
\hline $\mathrm{HC} 8$ & $\begin{array}{l}\text { Öztürk and } \\
\text { Sabırcan, } 2020\end{array}$ & $\begin{array}{l}\text { Health communication and } \\
\text { PSAs }\end{array}$ & $\begin{array}{l}\text { Quantative } \\
\text { research }\end{array}$ & $\begin{array}{l}\text { Reception theory was } \\
\text { mentioned }\end{array}$ \\
\hline HC9 & $\begin{array}{l}\text { Durmaz et al., } \\
2020\end{array}$ & Educational intervention & $\begin{array}{l}\text { Quantative } \\
\text { research }\end{array}$ & Health belief model was used \\
\hline HC10 & $\begin{array}{l}\text { Kahraman } \\
\text { and K1lıç, } \\
2019\end{array}$ & Medical civic action program & $\begin{array}{l}\text { Quantative } \\
\text { research }\end{array}$ & Health belief model was used \\
\hline HC11 & $\begin{array}{l}\text { Kartal et al., } \\
2017\end{array}$ & Educational intervention & $\begin{array}{l}\text { Quantative } \\
\text { research }\end{array}$ & Health belief model was used \\
\hline
\end{tabular}


T. Şentürk 13/4 (2021) 3293-3309

\begin{tabular}{|l|l|l|l|l|}
\hline HC12 & $\begin{array}{l}\text { Kahraman } \\
\text { and Akbulat, } \\
2015\end{array}$ & TV health programs and obesity & $\begin{array}{l}\text { Quantative } \\
\text { research }\end{array}$ & Health belief model was used \\
\hline HC13 & $\begin{array}{l}\text { Kartal and } \\
\text { Özsoy, 2014 }\end{array}$ & Educational intervention & $\begin{array}{l}\text { Quantative } \\
\text { research }\end{array}$ & Health belief model was used \\
\hline HC14 & $\begin{array}{l}\text { Olgun and } \\
\text { Altun, 2012 }\end{array}$ & Educational intervention & $\begin{array}{l}\text { Quantative } \\
\text { research }\end{array}$ & Health belief model was used \\
\hline HC15 & $\begin{array}{l}\text { K1liç and Erci, } \\
2007\end{array}$ & Educational intervention & $\begin{array}{l}\text { Quantative } \\
\text { research }\end{array}$ & Health belief model was used \\
\hline
\end{tabular}

In the studies in the field of health communication, it is seen that the uses and gratifications theory and the reception theory are predominantly used. In this framework, it has been determined that the authors tend to use theory and models in the analysis and evaluation stages, although they are mostly descriptive research frameworks. Also none of the researchers used Fishbein and Yzer's (2003) integrative model of behavioral prediction in their studies. In the studies coded as HC1, HC2 and HC3, the authors measured the motivation of a specific target audience to watch health-related media programs using the uses and gratifications theory. In this context, the researchers put forward a descriptive study. In the HC4 coded study, the researcher included a public service ad and two different anti-smoking commercials broadcasted by a private GSM company into analysis. In-depth interviews were conducted with nine different focus groups. Reception analyzes were used to determine how these films were interpreted by focus groups. In this framework, the author used reception theory within the framework of descriptive research. In the HC5 coded study, researchers used reception theory as an analysis method in campaign evaluation and measured the effectiveness of messages and visual content usage in health intervention campaigns. There is no reference to behavioral theories or models in the research. Instead, models used in communication and perception research such as hypodermic needle model, action-response model and symbolic perception model are mentioned. In the study coded HC6, behavioral insight applications in the field of health interventions were discussed. The activities revealed in these applications were evaluated within the framework of the nudge theory. Furthermore, the responses of patients to some applications were evaluated in the context of psychological reactance theory. In the HC7 coded study, the ELM model (Elaboration Likelihood Model) was used in the research design and data evaluation. Researchers recommend that those who investigate the role of health communication messages in persuasion and attitude change, should measure the effect levels of communication messages using central and peripheral cues within the scope of ELM. In the study coded HC8, the authors mentioned that dominant reception, negotiated reception and oppositional reception were used in the analysis in the method part of the research and explained these reception models in the method part. However, there is no reference to the relevant reception models in the evaluation parts and the conclusion part of the research. In the studies coded as HC9, HC10, HC11, HC12, HC13, HC14 and HC15 health belief model was used for descriptive research or evaluation. Especially educational health intervention studies prefer health belief model for the descriptive research and evaluation. The ability of the health belief model to reveal a specific research scale for a specific health problem, as in the case of obesity and prostate cancer, stands out as an important ability of the model. It has been the most common model in health intervention studies in the literature review. The use of the model mostly emerges as a result of health education interventions. It is also used to measure the impact of TV health programs and beliefs and attitudes about health screenings. 
Table 5. Use of Theory and Model in PSA Studies

\begin{tabular}{|l|l|l|l|l|}
\hline Code & Researchers & Research Field & Research Type & Theory and/or Model Use \\
\hline PSA1 & $\begin{array}{l}\text { Özüpek and } \\
\text { Özer, 2018 }\end{array}$ & $\begin{array}{l}\text { Smoking } \\
\text { addiction }\end{array}$ & $\begin{array}{l}\text { Qualitative } \\
\text { research }\end{array}$ & $\begin{array}{l}\text { The models using in the frame of } \\
\text { neuroimaging was mentioned }\end{array}$ \\
\hline PSA2 & İnci et al., 2017 & $\begin{array}{l}\text { PSA content } \\
\text { analysis }\end{array}$ & $\begin{array}{l}\text { Quantative } \\
\text { research }\end{array}$ & $\begin{array}{l}\text { Behavioral theories that are frequently used } \\
\text { in health interventions was mentioned }\end{array}$ \\
\hline PSA3 & Akova, 2017 & $\begin{array}{l}\text { Smoking } \\
\text { addiction }\end{array}$ & $\begin{array}{l}\text { Quantative } \\
\text { research }\end{array}$ & $\begin{array}{l}\text { Protection motivation theory and reception } \\
\text { theory was used }\end{array}$ \\
\hline
\end{tabular}

The use of theory and models in public service announcements about health interventions is extremely limited. In this framework, no particular theory or model came to the fore. No reference was made to any theory in the evaluation of descriptive research or findings in the study coded PSA1. Only some models related to neuroimaging are explained in the theoretical background of the study.

In the study coded PSA2, the researchers explained the effect to be achieved by the use of famous people in public service ads with social learning theory. In addition, it has been suggested in the research that social marketers, like commercial marketers, use regulatory focus theory in message design. In addition, behavioral theories that are frequently used in health interventions were explained. In the study coded as PSA3, the researcher stated that the use of public service announcements is increasing day by day and agenda setting by attracting the attention of the public is one of the aims of the PSAs. In this context, the author referred to the agenda setting theory. In the literature review section, the author also analyzed three public service announcements published within the scope of fight against smoking within the framework of protection motivation theory. In the sample analysis section of the study, it is stated that the fear and anxiety factors are given as a sub-message within the framework of protection motivation theory. In the study, the analyzes of the relevant public service announcements on the focus groups were made with reception analyzes in the context of reception theory.

\section{CONCLUSION AND DISCUSSION}

The Covid-19 pandemic has shown us very dramaticly what tragedies the failure of positive behavior change in individuals can cause (Şentürk, 2021). These tragedies reveal that the issue of persuasion is not only the responsibility of the business world and marketers. On the contrary, it turns out that all parties who have a say in society, from states to NGOs, must acquire skills in social persuasion and behavior change.

Although it is seen that the authors in the field of social marketing questioned the use of theory and model in the previous systematic reviews (see Buyucek et. al., 2016; Lefebvre, 2000; Luca and Suggs, 2013; Truong, 2014), it is seen that they do not question the validation of the studies discussed. In other words, the use of theory and model in social marketing studies in the field of health interventions is examined in the literature, but the compliance of these studies with international standards is not questioned. For this reason, the validation of the articles examined in this study was also included in the scope of the research. As a result of the validation study, it was found that social marketing, social advertising, health communication and public service advertisements on health interventions in Turkey met international norms at a high rate. In the validation study carried out within the scope of the research, the agreement between the observers for qualitative and quantitative studies is quite high. It has been observed that all the studies evaluated comply with international 
standards by more than $60 \%$. In this case, it can be said deterministically that the suggestions to be given or compiled on the subject of the study meet both national and international norms and their scientific quality meets the expectations. In this context, the validation research revealed that a) the studies included in the research have international standards; $b$ ) the conclusions and recommendations to be drawn are derived from studies with high standards.

According to the results of the systematic review, it was seen that the use of theory and model in social marketing, social advertising, health communication and public service advertisements on health interventions in Turkey is extremely limited. These findings are in line with those in the international literature (see Lefebvre, 2000; Luca and Suggs, 2013; Thackeray and Neiger, 2000). It has been determined that the use of theory and model in social marketing and health communication studies in Turkey is mostly applied in the descriptive research phase. In addition, the use of theory and models was observed in the campaign stages and evaluation processes. It has been determined that the use of theory and model in public service announcements about health interventions is low both in general and compared to social marketing and health communication research.

In this research, it was seen that the exchange theory was referred to in social marketing studies, but the relevant theory was not used in the descriptive research, campaign design and evaluation stages in those studies. The exchange theory is either explained or a small perspective on its use is presented. It has been determined that stages of change model (transtheoretical model), health promotion model and theory of planned behavior are used in social marketing studies.

It has been seen that reception theory and helath belief model is mostly used in health communication studies. Apart from this, it has been determined that models used in communication and perception researches such as hypodermic needle model, action-response model and symbolic perception model are used. In addition, in one study, the Elaboration Likelihood Model was used in research design and data evaluation, and this use was suggested for new research.

It has been observed that the use of theory and models in public service advertisements is very limited. In the identified studies, regulatory focus theory has been proposed for message design and agenda setting theory has been proposed to create an agenda. In the campaign evaluation, social learning theory, reception theory and protection motivation theory were either used or suggested.

These results support the call made by Lefebvre (2000) over two decades ago to focus on the use of theory and models for better intervention design and reporting. Since behavioral theory is defined as one of the benchmark criteria of social marketing, it is accepted as one of the main elements of the social marketing process (Luca and Suggs, 2013:37). Although the connection between theory and model use in the development of social marketing studies and well-designed interventions has been revealed in the literature (Lombardo and Le'ger, 2007), it is seen in the literature review that a large number of social marketing studies in Turkey do not report theory and model use in detail. This result is also similar to the international literature (see Lefebvre, 2000; Luca and Suggs, 2013; Truong, 2014). In addition to this finding, it has been determained that the most of the social marketing and PSA studies using theory and model on health interventions in Turkey deal with tobacco use.

Özbük and Öz (2017: 585) state that the vast majority of public service advertisements in Turkey have an encouraging message design, yet the behavioural change success of the PSAs is only $20 \%$. When the findings obtained in this study are combined with the findings of Özübük and Öz (2017), it can be said that the public service programs designed by using behavioral theories will produce more beneficial results.

The use of theory and model in the field of health communication is more than social marketing and public service announcements fields in Turkey. However, it has been determined that studies using theory and models in health communication field mostly work on health program audiences or PSAs. In these studies, it was also observed that none of them used the Fishbein and Yzer's well-respected integrative model of 
behavioral prediction. In this context, it can be deduced that researchers working in health communication in Turkey do not consider the relevant model or do not focus fully on benefiting from the theory and model in behavior change in health communication.

There are many theories and models that social marketers can use when designing, implementing and evaluating health interventions. However, this exploitation effort should first start with knowing the distinction between theory and model (Lefebvre, 2000). Then, social marketers should identify the theories and models that they can use within the framework of their goals and should have a good grasp of the literature and practices related to them. In particular, the literature for the integration of theory/model and health intervention should be examined, and then conclusions should be drawn. The social marketer, who has also mastered the integration issue, can now design social interventions with the support of one or more theories or models, and carry out the implementation and evaluation processes much more accurately.

As an implication of the findings, it can be said that an approach that will encourage researchers in social marketing studies and intervention designs should be developed. Supporting new researchers and practitioners with state of the art studies by researchers who have been working in social marketing field for many years both in Turkey and in the world can be of great benefit. With the increasing number of "guide studies" in the literature, the attention and enthusiasm of new researchers may be focused on making use of theory and models. In addition, studies in the field of health interventions need to be supported and diversified with studies other than smoking and audience analysis.

\section{REFERENCES}

Akova, S. (2017). "Sigarayi Birak, Hayati Birakma" sloganli kamu spotlari örneklemlerinin alimlama analizi yöntemi ile incelenmesi. Stratejik Sosyal Araştırmalar Dergisi. 1(2), 15-36.

Avcı, İ. B. ve Sönmez, M. F. (2013). Sağlik iletişimi bağlaminda bireylerin televizyonda yayınlanan sağlık programlarını izleme alışkanlıkları ve motivasyonları: Elaziğ örneği. Gümüşhane Üniversitesi İletişim Fakültesi Elektronik Dergisi. 2(2), 119-138.

Becerikli, S. Y. (2012). Sağlik iletişimi çalişmalarinda alimlama analizinin kullanimi: Odak grup çalişmasi yoluyla kamu kampanyalari ve reklam metinlerine ilişkin çapraz bir okuma pratiği, İstanbul Üniversitesi İletişim Fakültesi Dergisi, II, 43, 163-177.

Bickman, L. (1972). Environmental attitudes and actions. Journal of Social Psychology, 87, 323-324.

Bilir, N. ve Özcebe H. (2014). Tobacco dependence and control: Individual, community approaches and social marketing method. Eurasian J Pulmonol; 16: 63-8.

Bland, J. M. and Altman, D. G., (1986). Statistical methods for assessing agreement between two methods of clinical measurement. Lancet; I, 307-10.

Bulduklu, Y. (2010). Televizyonda yayınlanan sağlık programları ve izleyicileri. Selçuk Üniversitesi Sosyal Bilimler Enstitüsü Dergisi. 24, 75-85.

Buyucek, N., Kubacki, K., Rundle-Thiele S., Bo Pang. (2016). A systematic review of stakeholder involvement in social marketing interventions. Australasian Marketing Journal, 24, pp: 8-19.

Cassar, L. F., Conrad E., Bell S. and Morse S. (2013). Assessing the use and influence of sustainability indicators at the European periphery. Ecological Indicators, 35, 52-61.

Cheng H., Kotler P. and Lee N. (2010). Social Marketing for Public Health: Global Trends and Success Stories. Jones and Bartlett Publishers, LLC.

Çelik, S. (2016). A new method of social marketing: Community based social marketing". Journal of Human Sciences, 13(2), 3057-3072. 
Çevik Durmaz Y, Doğan R, Türkben Polat H, Uzun E, Şakar H, Yalçınkaya Önder E. (2020). Üniversite öğrencilerine verilen meme kanseri ve kendi kendine meme muayenesine yönelik eğitimin öğrencilerin kaygı düzeyine ve sağlık inançlarına etkisi. Anadolu Hemşirelik ve Sağlık Bilimleri Dergisi,;23(2):259266. DOI: 10.17049 /ataunihem.550674

Çınarlı, İ. (2008). Sağlık İletişimi ve Medya, Ankara: Nobel Yayınları.

Çoknaz, D. Umut, Özbakır, M. ve Velioğlu, Nurtanış M. (2016). Sosyal pazarlamada hazır kitleyi bulmak ve haritalamak: Baby boomers'larda fiziksel aktiviteye yönelik araştırma. Eskişehir Osmangazi Üniversitesi Sosyal Bilimler Dergisi. 17(2), 81-105.

Ekiyor, A. ve Çetin, A. (2017). Sağlık hizmeti sunumunda ve sosyal pazarlama kapsamında e-Nabız uygulamasının bilinirliği. Uluslararası Sağ̆lk Yönetimi ve Stratejileri Araştırma Dergisi, 3(1), 88-103.

Ekren, D. C. and Şentürk, T. (2021). How can social marketing and social enterprises promote sustainable development in covid-19 world and beyond? The Journal of International Social Research, 14 (77), 12801294.

Fidan, M. ve Yetiş, A. (2018). Sağlik iletişiminde alg1: Kamu spotlari üzerine bir araştırma. Selçuk İletişim. 11 (2): 159-178.

Fishbein, M. and Yzer, M. C. (2003). Using theory to design effective health behavior interventions. Communication Theory. 13(2), 164-183.

Futterman, D. C., Peralta, M. D., Rudy, B. J., Wolfson, S., Guttmacher, S., \& Rogers, A. S. (2001). The ACCESS (Adolescents Connected to Care, Evaluation, and Special Services) project: Social marketing to promote HIV testing to adolescents, methods and first year results from a six city campaign. Journal of Adolescent Health, 29S, 19-29.

Gallivan, J., Lising, M., Ammary, N. J., \& Greenberg, R. (2007). The national diabetes education program's "control your diabetes. For Life" campaign: Design, implementation, and lessons learned. Social Marketing Quarterly, 13, 65-82

Geller, E. S. (1981). Evaluating energy conservation programs: Is verbal report enough? Journal of Consumer Research, 8, December, 331-335.

Geller, E. S., Erickson, J. B. and Buttram, B. A. (1983). Attempts to promote residential water conservation with educational, behavioral and engineering strategies. Population and Environment Behavioral and Social Issues, 6, 96-112.

Gençoğlu, P., Bağlitaş H. H. and Kuşkaya S. (2017). Effects of public service announcements on individuals' behaviors as a socialmarketing: A non-parametric statistical analysis. The Journal of International Social Research. 10(48), 622-629.

Hastings, G. and Saren, M. (2003). The critical contribution of social marketing theory and application. Marketing Theory. 3(3): 305-322.

İnci, B., Sancar, O. ve Bostanc1, S. H. (2017). Usage of health-themed public service announcements as a social marketing communication tool: A content analysis related to public service announcements in the republic of Turkey, ministry of health's web site. Marketing and Branding Research. 4, 148-168.

Kahraman, F. ve Kılıç, D. (2019). 40 Yaş Üzeri Bireylerin Prostat Kanseri Taramalarına İlişkin Sağlık İnanç ve Tutumlarının Belirlenmesi. Halk Sağliği Hemşireliği Dergisi, 1(3), 103-118.

Kahraman G., Baş T. ve Akbolat M. (2015). Obeziteye Yönelik Tutum ve İnançların Geliştirilmesinde Sağlık Programlarının Etkisi. Acıbadem Üniversitesi Sağlık Bilimleri Dergisi, 6(2), 89-98. 
Kartal, A. ve Özsoy Altuğ S. (2014). Tip 2 diyabetli hastalarda planlı eğitim programının sağlık inancına ve metabolik kontrole etkisi. Hacettepe Üniversitesi Hemşirelik Fakültesi Dergisi, 1-15.

Kartal A., İnci F. H., Koştu N. ve Çinar İ. Ö. (2017). Kadınlara ev ortamında verilen bireysel eğitimin kendi kendine meme muayenesi uygulamasına yönelik sağlık inançlarına etkisi. Pamukkale Tip Dergisi, 1, 7-13.

Kiliç, D. ve Erci, B. (2007). Premenopozal dönemdeki kadinlara verilen eğitimin osteoporoza ilişkin sağlik inançlari ve bilgi düzeylerine etkisi. Atatürk Üniversitesi Hemşirelik Yüksekokulu Dergisi, 10(3), 34-44.

Koçak, A. ve Bulduklu, Y. (2010). Sağlik iletişimi: yaşlilarin televizyonda yayinlanan sağlik programlarini izleme motivasyonları. Selçuk İletişim. 6(3), 5-17.

Kotler, P. and Zaltman, G. (1971). Social marketing: an approach to planned social change, Journal of Marketing, 35, July, 3-12.

Lee, N. R. ve Kotler, P. (2011). Social Marketing: Influencing Behaviors for Good (4th ed). Thousand Oaks, CA: SAGE Publications.

Lefebvre, C. R. (2000). Theories and models in social marketing. In P. N. Bloom \& G. T. Gundlach (Eds.), Handbook of marketing and society (pp. 506-519). Newbury Park, CA: Sage.

Lombardo, A. P., and Le'ger, Y. A. (2007). Thinking about "Think Again" in Canada: Assessing a social marketing HIV=AIDS prevention campaign. Journal of Health Communication, 12, 377-397.

Long, T., Taubenheim, A. M., Wayman, J., Temple, S., \& Ruoff, B. A. (2008). The health truth: Using the power of branding and social marketing to increase awareness of heart diseases in women. Social Marketing Quarterly, 14, 3-29.

Luca, N., \& Suggs, L. S. (2013). Theory and model use in social marketing health interventions. Journal of Health Communication, 18(1), 20-40.

McKenzie-Mohr, D., and Smith, W. (1999). Fostering Sustainable Behavior: An Introduction to Community-Based Social Marketing (2nd ed.). Gabriola Island, British Columbia, Canada: New Society.

McKenzie-Mohr, D. (2000). Promoting sustainable behavior: an introduction to community-based social marketing, Journal of Social Issues, 56(3), 543-554.

Nakıboğlu, B. (2016). Güneşten korunma ile ilgili sosyal pazarlama kampanyaları için davranışsal bulgular. Çukurova Üniversitesi Sosyal Bilimler Enstitüsü Dergisi, 25(1), 183-204.

Okay, A. (2007). Sağlık İletişimi, İstanbul: MediaCat Yayınları.

Okmeydan, B. S. (2018). Dumansız Hava Sahası Kampanyası Ekseninde Sosyal Pazarlama Kampanya Basamakları. Gümüşhane Üniversitesi İletişim Fakültesi Elektronik Dergisi. 6(1), 502-538.

Olgun, N. ve Akdoğan Altun, Z. (2012). Sağllk inanç modeli doğrultusunda verilen eğitimin diyabet hastalarının bakım uygulamalarına etkisi. Sağlık Bilimleri Fakültesi Hemşirelik Dergisi, 46-57.

Özbük, M. Y. and Öz, Y. (2017). Examination of public service announcements in Turkey through content analysis method. Business and Economics Research Journal. 8(3), 575-589.

Özdemir, Ş. (2019). Sağlık iletişiminde davranışsal müdahale tasarımı: İngiltere online hastane randevu sistemi örneğ. C.Ü. İktisadi ve İdari Bilimler Dergisi. 20(1), 348-365.

Öztürk, İ. D. ve Sabırcan, F. (2020). Sağlik iletişiminde kamu spotu kullanimi üzerine bir değerlendirme “Sen de Başarabilirsin" kamu spotu örneği. İstanbul Kent Üniversitesi İnsan ve Toplum Bilimleri Dergisi. 1(1), 34-51. 
Özüpek, M. N. ve Özer, D. (2018). Sigara karşıtı kamu spotlarının bireyler üzerindeki etkisinin nörogörüntüleme yöntemiyle tespit edilmesi. OPUS-Uluslararası Toplum Araştırmaları Dergisi, 9(16), 183-215.

Pang, B., Rundle-Thiele, S. R., \& Kubacki, K. (2017). An empirical examination of the ecological and cognitive active commuting framework: A social marketing formative research study. Health Education, 117(6), $581-598$.

Pang, B., Rundle-Thiele, S., \& Kubacki, K. (2018). Can the theory of planned behaviour explain walking to and from school among Australian children? A social marketing formative research study. International Journal of Nonprofit and Voluntary Sector Marketing, 23(2), e1599.

Park, K., Hong, W. H., Kye, S. Y., Jung, E., Kim, M., \& Park, H. G. (2011). Community-based intervention to promote breast cancer awareness and screening: The Korean experience. BMC Public Health, 11, 468478.

Rundle-Thiele S., Patricia D., Taylor W., Bo P., Lynne E. \& Rachel H. (2019) Social marketing theory development goals: an agenda to drive change, Journal of Marketing Management, 35:1-2, 160-181, DOI: 10.1080/0267257X.2018.1559871

Şahin, E. ve Duğan, Ö. (2020). Dijital Çağın Mizahi Anlatım Türü Capslerle Sağlık Konulu Mesajların Yayılımı. International Journal of Cultural and Social Studies (IntJCSS). 6 (1), 191-207.

Şentürk, T. (2021). Rethinking social marketing and behavioural change in times of covid-19 pandemic. Manisa Celal Bayar University Journal of Social Sciences; 19(1); 321-338.

Thackeray, R. and Neiger, B. L. (2000). Establishing a relationship between behavior change theory and social marketing: implications for health education. Journal of Health Education, 31(6), 331-335.

Tokay Argan, M. (2016). Kan bağış davranışını etkileyen faktörlerin planlı davranış teorisi çerçevesinde incelenmesi. ACU Să̆lık Bilimleri Dergisi, (2):96-104.

Torun, T. ve Ekinci F. (2014). Sigara ve benzer nitelikli alişkanlik yaratan ürünlerin tüketiminin azaltilmasina yönelik sosyal pazarlama uygulamalarında vergilerin etkinliği. Sakarya İktisat Dergisi. 3(2), 19 - 39.

Truong, V. D. (2014). Social marketing: A systematic review of research 1998-2012. Social Marketing Quarterly, Vol. 20(1) 15-34.

UN, (2020). World social report: Inequality in a rapid changing world, (Retrieved form www.un.org/development/desa/dspd/wp-content/uploads/sites/22/2020/01/World-Social-Report-2020FullReport.pdf, access date: 02.12.2021).

Wiebe, G. D. (1952). Merchandising commodoties and citizenship on television. Public Opinion Quarterly. Vol. 15, 679-691.

Wymer, W. (2015). Innovations in Social Marketing and Public Health Communication. Springer International Publishing. 